\title{
A pena e a espada a Revue des Deux Mondes e a intervenção francesa no México*
}

\section{The pen and the sword}

Revue des deux Mondes and the French intervention in Mexico

\author{
MARIA LIGIA COELHO PRADO** \\ Departamento de História \\ Universidade de São Paulo \\ São Paulo (SP) \\ Brasil
}

\begin{abstract}
RESUMO Este artigo analisa os textos publicados pela Revue des Deux Mondes a respeito do México, entre 1840 e 1870. A revista expressava a opinião de grupos de intelectuais próximos ao poder político, entendidos aqui como representantes dos interesses nacionais franceses. O México se distinguia, na América Latina, como centro principal de suas atenções. A revista elaborou imagens da França como o mais importante país latino que olhava para sua "irmã de sangue", a nação mexicana, com o desejo de dirigir seus passos. Os artigos lembravam o glorioso passado da França e insistiam na necessidade do país se interpor ao avanço, na região, de sua grande rival, a Grã-Bretanha, e da nova "ameaça", os Estados Unidos. Os articulistas estimularam seus leitores a pensarem a França como grande potência colocada em lugar de preeminência internacional legitimado por sua história, cultura e civilização.
\end{abstract}

Palavras-chave Revue des Deux Mondes, intelectuais, França, México, século XIX

\footnotetext{
Artigo recebido em: 17/02/2014. Autora convidada.

** Profa. Titular de História da América Independente do Departamento de História da FFLCH/USP.
} 
ABSTRACT This research intends to analyze the articles about Mexico published by the Revue des Deux Mondes between 1840 and 1870. The magazine expressed the opinion of intellectuals which were close to political power and thought themselves as the voice of national French interests. The Revue chose Mexico as the center of its attention in Latin America. The authors elaborated images of France as the most important Latin country looking at Mexico as its "blood sister" which needed to be guided. The articles emphasized the glorious past of France and insisted that the country must balance, in Latin America, the power of its great rival, Great Britain, and the "threat" represented by the United States. The authors stimulated their readers to think of France as a great nation with an extraordinary history, culture and civilization.

Keywords Revue des Deux Mondes, intellectuals, France, Mexico, 19th century

No século XIX, as revistas como produto cultural e político estavam associadas, de modo geral, à defesa de ideias e posições vinculadas a um determinado grupo político, assim como a discussões sobre literatura, arte e filosofia. ${ }^{1}$ Essas publicações, criadas por intelectuais, mostravam-se como o meio mais eficaz para atingir os objetivos almejados, pois podiam fazer circular suas propostas de maneira adensada e com certa rapidez. ${ }^{2}$ Mas é preciso lembrar que, nesse período, no campo dos impressos, as revistas restringiam-se a um pequeno círculo de leitores e enfrentavam dificuldades de sobrevivência, já que dependiam das poucas assinaturas do público, não veiculavam anúncios de propaganda e tinham limitações técnicas e custos altos no que se referia à impressão.

A Revue des Deux Mondes, Recueil de la politique, de l'administration et des moeurs, minha fonte de pesquisa, enquadra-se nessa ampla moldura. ${ }^{3}$ Foi fundada em 1829, por dois homens que marcavam, já de início, o caráter da revista: um intelectual, Prosper Mauroy, e um político, Ségur-Dupeyron. Seu primeiro exemplar veio a lume em agosto de 1829, em formato in-8 ${ }^{\circ}$,

1 Concordo com Beatriz Sarlo, para quem a iniciativa de publicar uma revista representa a decisão de fazer política cultural; SARLO, Beatriz. Intelectuales y revistas: razones de una práctica. América - Cahiers du CRICCAL, Paris, n.9-10, p.9, 1992

2 Conforme Regina Crespo, que reflete sobre revistas latino-americanas do século XX; mas essa perspectiva também se ajusta a meu objeto de estudo; CRESPO, Regina. Introdução. In: CRESPO, Regina (org.). Revistas en América Latina: proyectos literarios, políticos y culturales. México: Universidad Nacional Autónoma de México/Ediciones y Gráficos Eón, 2010, p.14

3 Nas últimas décadas, os historiadores têm tomado as revistas, em especial as editadas no século XX, como fonte de pesquisa, daí resultando trabalhos de grande importância e interesse. Ver: DE LUCA, Tânia Regina. História dos, nos e por meio dos periódicos. In: PINSKY, Carla Bassanezi (org.). Fontes históricas. São Paulo: Contexto, 2005. 
com 128 páginas, que se ampliaram em muito com o passar dos anos. O modelo que inspirou seus criadores foi a prestigiada Edinburgh Review, nascida em 1802, periódico literário e político que deu forte sustentação às posições do partido Whig. ${ }^{4}$ Quando surgiu a Revue, circulavam pela França outros magazines de natureza semelhante como, por exemplo, o Mercure du XIXe siècle, dedicado à literatura (1823-1832), ou o Le Globe (18241832), de Pierre Leroux que, em seu período final, defendeu a doutrina de Saint-Simon. No mesmo ano de 1829, aparecia a Revue de Paris, editada por Louis-Désiré Véron, e que faria concorrência direta com a Revue des Deux Mondes. ${ }^{5}$

Com poucos assinantes, num espaço cultural pequeno e competitivo, não é difícil entender porque, dois anos depois, a Revue estava à beira da falência. Foi vendida, em 1831, a Auguste Auffray, que convidou François Buloz para assumir sua direção. Considerado o "verdadeiro" fundador da revista, Buloz comprou-a, em 1833, com financiamento de amigos - Félix e Florestan Bonnaire -, permanecendo no cargo até sua morte em 1877. A estratégia do novo diretor foi a de conseguir importantes e constantes colaboradores que dessem à publicação um perfil de competência e confiabilidade. Sua particularidade, como afirmavam os editores, era alcançar o objetivo de "conhecer o que se passa ou o que se passou com outros povos", ${ }^{6}$ por meio de textos elaborados por autores com conhecimento comprovado sobre questões estrangeiras, que tivessem, de preferência, vivido em terras longínquas. A experiência in loco conferia credibilidade às informações e análises escritas, indicando que estava se consolidando uma nova maneira de articular o conhecimento sobre o mundo extra-europeu com a experiência pessoal dos escritores.

Mas o universo cultural e político francês ocupava o centro das atenções da revista. Desse modo, Buloz conseguiu reunir uma plêiade de importantes escritores e pensadores franceses - como Alfred de Vigny, Alfred de Musset, George Sand, François Guizot, Jacques Nicolas Augustin Thierry, Charles Augustin Sainte-Beuve, Gustave Planche, Auguste de Saint-Hilaire, Eugène Lerminier, Edgard Quinet - que analisavam temas literários e artísticos ao lado de questões filosóficas, históricas, científicas, políticas e econômicas.

4 A Edinburgh Review teve Francis Jeffrey como primeiro editor-chefe permanente e foi uma das mais distinguidas revistas britânicas do século XIX. Foi editada até 1929. A defesa das posições partidárias liberais expressas pela Edinburgh Review fez aparecer uma rival, já em 1809, a Quarterly Review, que apoiava os Tories. As primeiras publicações com características mais definidas do que passou a ser classificado como revista começaram a surgir na Europa no século XVII. No século XVIII, um maior número de revistas apareceu, tratando de temas bastante diversos, da literatura à política e aos costumes; na Inglaterra, teve longa vida a The Monthly Review (1749-1845), criada pelo inglês Ralph Griffiths, dissidente da Igreja Anglicana.

5 Outro problema enfrentado por todas as revistas (e também pelos livros de sucesso) eram as contrafações belgas, publicações piratas que copiavam textos em papel barato e os vendiam por preço mais baixo.

6 Revue de Deux Mondes, Paris, t.I, p.1, 1829. É preciso informar que a revista, em 1831, tinha 350 assinantes; em torno de 2.000, em 1840; e 15.000, em 1863. Cf. LOUÉ, Thomas. La Revue des Deux Mondes de Buloz à Brunetière: de la Belle Époque de la revue à la revue de la Belle Époque. Paris: Université de Paris I - Sorbonne, 1998 (História, Tese de doutorado). 
A literatura francesa, por exemplo, tinha primazia em mais de uma seção da Revue, mas reservou-se espaço para as obras de autores de outros países europeus e americanos.

Depois de 1833, a Revue se consolidou e encontrou seu lugar como importante revista de cultura geral, dirigindo-se a uma elite intelectual na França e no exterior. Como indicou a crítica literária Annette Paatz, a revista pode ser entendida como uma metonímia da cultura francesa. Esteve associada, pelo menos na década de 1830, ao movimento romântico, que propunha um conceito nacionalista de cultura e defendia uma visão homogeneizadora e essencialista de cultura. ${ }^{7}$ Do ponto de vista político, seu núcleo de intelectuais não se situou à margem do poder e, por isso mesmo, a revista não conheceu, até 1877, desventuras econômicas ou vacilações ideológicas. No período que pretendo analisar - desde sua fundação em 1829 até 1870 - a Revue se posicionou como defensora da monarquia francesa e do grupo orleanista. Num amplo espectro político, colocou-se no campo da direita moderada e constitucional. Depois de 1848, suas posições foram se tornando mais conservadoras.

A Revue, que oferece um manancial de temas a serem explorados pelo pesquisador, tem sido objeto de estudos mais amplos ${ }^{8}$ e também de trabalhos, em especial de críticos literários, que buscaram entender, sob a ótica da revista, questões particulares referentes, por exemplo, ao realismo literário, ao naturalismo, ao romance russo, à literatura norte-americana. ${ }^{9}$

O mundo todo foi alvo de seu interesse e os longos artigos traziam narrativas históricas sobre o passado e informações detalhadas e dados abundantes sobre o momento contemporâneo. Surpreende, por exemplo, que tenham publicado artigos sobre fatos recém acontecidos como os casos a seguir: "notícias sobre a expedição à Antártida", de 1830; "história e colonização da Nova Zelândia", de 1840; "os negros livres na Libéria", de 1852; "Walker na Nicarágua", de 1856; ou "Ema, rainha das ilhas do Havaí", de 1885.

7 Cf. PAATZ, Annette. The socio-cultural function of media in nineteenth-century Latin America. CLCWeb: Comparative Literature and Culture, v.3, p. 2001. Disponível em: <http://dx.doi.org/10.7771/1481-4374.1120>. Acesso em: 30 out. 2013.

8 Além do já citado Thomas Loué, que estuda as condições de produção material da revista, veja-se o livro de: BROGLIE, Gabriel de. Histoire politique de la "Revue des Deux mondes" de 1829 à 1979. Paris: Perrin, 1979; GOBERT, Jean-Marie. L'itinéraire intellectuel et politique de "La Revue des Deux Mondes", 1848-1893. Paris: Institut d'Études Politiques, 1985 (História, Tese de doutorado); KARAKATSOULIS, Anne. La Revue des Deux Mondes de 1920 à 1940: une revue française devant l'étranger. Paris: École des Hautes Études en Sciences Sociales, 1995 (Tese de doutorado).

9 Sobre o Brasil, ver CAMARGO, Kátia Aily Franco de. A Revue des Deux Mondes: uma intermediária entre dois mundos. Natal: EDUFRN, 2007, que "busca estudar a presença de imagens brasileiras" na revista, entre 1829 e 1893; SILVA, Ligia Osorio; DANTAS, Luiz. Letras brasileiras na Revue des Deux Mondes. In. NITRINI, Sandra (org.). Aquém e além mar: relações culturais: Brasil-França. São Paulo: HUCITEC, 2000; SILVA, Ligia Osorio. Propaganda e realidade: a imagem do Império do Brasil nas publicações francesas do século XIX. Theomai, Buenos Aires, v.3, p. 25-50, 2001; VIDAL, Laurent; DE LUCA, Tânia Regina (orgs.). Franceses no Brasil: séculos XIX-XX. São Paulo: Editora da Unesp, 2009. 
O olhar universalista que guiava a publicação fez também da América Latina seu objeto de atenção com textos que versavam sobre acontecimentos políticos, dados econômicos, aspectos culturais e as relações da região com a França. ${ }^{10}$ No amplo espectro de interesses da revista, os latino-americanos ocupavam um lugar secundário, contando com uma pequena produção de artigos em comparação com a importância dada a alguns países da Europa - Grã-Bretanha, Prússia, Rússia - e, embora não no mesmo nível, aos Estados Unidos. ${ }^{11}$ Mas há muitos indícios e registros que mostram que, entre os grupos letrados latino-americanos, o periódico foi muito lido e produziu grande impacto, incomparavelmente superior à menor penetração de suas variantes anglo-saxônicas. A Revue cumpriu um papel de mediadora cultural e transmitiu informações muitas vezes inacessíveis aos latino-americanos que estavam restritos ao conhecimento de questões referentes a seu próprio país. Ofereceu informação sobre acontecimentos sociais, políticos, geográficos e literários da Europa e do continente americano. Além disso, proveu os latino-americanos com avaliações e julgamentos sobre arte e literatura em resenhas e comentários que foram formando seu gosto literário e artístico.

Como bem se conhece, a historiografia apresenta a França, no século XIX, como pólo irradiador de ideias políticas e de modelos culturais para a América Latina, sendo ela a principal referência no que concerne o mundo literário e artístico em geral. Os artigos da Revue se constituem em registro desse papel assumido pelas elites letradas francesas. Mas também apontam para outros aspectos das relações entre a América Latina e a França que não são comumente salientados. Desse modo, tomo a Revue como espaço fundamental para se entender as manifestações de defesa

10 A respeito das representações sobre a América Latina elaboradas pela Revue e sobre a circulação de ideias entre a França e a América Latina no século XIX, ver: PRADO, Maria Ligia Coelho. Leituras políticas e a circulação de ideias entre a França e as Américas: Francisco Bilbao e a Revue des Deux Mondes. In: BEIRED, José Luis Bendicho; CAPELATO, Maria Helena Rolim; PRADO, Maria Ligia Coelho (orgs.). Intercâmbios políticos e mediações culturais nas Américas. Assis/São Paulo: FCL-Assis-Unesp Publicações/Laboratório de Estudos de História das Américas-FFLCH-USP, 2010, p.193-206; SOARES, Gabriela Pellegrino. A Revue des Deux Mondes em face da América Espanhola oitocentista: projeções imperiais e apropriações nacionais. In: BEIRED, José Luis Bendicho; CAPELATO, Maria Helena Rolim; PRADO, Maria Ligia Coelho (orgs.). Intercâmbios políticos e mediações culturais nas Américas. Neste último artigo, a autora mostra como Domingo Faustino Sarmiento, perfeitamente ciente da importância da Revue, insistiu e conseguiu ter uma resenha de seu Facundo, escrita por Charles de Mazade, publicada na revista em 1846. Este foi um dos fatores que fizeram seu livro ser conhecido na América Latina.

11 Do mesmo modo, nas pesquisas realizadas por mim e por Gabriela Pellegrino Soares, nos arquivos dos Bureaux et Bibliothèque do Institut de Mémoire de I'Edition Contemporaine (IMEC) em Paris e nos arquivos da Revue administrados pelo IMEC, depositados na abadia de Ardenne (nos arredores de Cäen, na Normandia), pouco material sobre a América Latina foi encontrado. A parte essencial dos documentos refere-se à economia e à gestão da revista, com muitos documentos contábeis e inventários. Não encontramos, por exemplo, para o período estudado, listas de assinantes latino-americanos da revista, sendo a mais antiga (e incompleta) de 1899. A relação das distribuidoras da Revue, com data de 1889/1890, indica a existência de várias casas distribuidoras na Europa (5 na Inglaterra, 5 na Alemanha, 6 na Itália, 2 na Espanha), apenas uma nos Estados Unidos, a International News de Nova York, e nenhuma na América Latina. Num quadro de contatos de negócios de Buloz no estrangeiro, entre 1848 e 1852, além dos europeus, aparecem quatro nos Estados Unidos e nenhum na América Latina. As assinaturas de latino-americanos - individuais ou de uma instituição - eram feitas por intermédio de casas europeias ou norte-americanas. 
de projetos franceses pela conquista da hegemonia política e econômica na América Latina.

Não há nada de novo ao se afirmar que a Revue olhava para o mundo com uma fortíssima fixação francocêntrica e que sua abordagem sobre o mundo extra-europeu tinha como ponto central de referência os interesses nacionais franceses. Contudo vale enfatizar que os artigos políticos sobre o mundo extra-europeu mostravam o emprego constante, pelos autores da revista, do pronome nós e do possessivo nosso, que os transformava em representantes da França e de sua visão imperial. É possível acompanhar as posições sobre o desejado - e pensado como legítimo e merecido - lugar da França no cenário internacional, não apenas em termos de hegemonia cultural, mas também de geopolítica e de domínio de mercados.

Charles de Mazade (1820-1893), um dos articulistas mais importantes da Revue e autor de diversos artigos sobre a América Latina, sintetizou em duas frases a visão sobre o desejo de primazia da França no mundo do século XIX:

A França é o ministro universal das nações, a reguladora soberana de seus movimentos e de seus pensamentos; ela goza da maravilhosa vantagem de Ihes providenciar sistemas e novidades. ${ }^{12}$

Essas afirmações, dentre muitas outras com sentido semelhante, são reveladoras da perspectiva imperial francesa que se manifestava de forma repetida. Tome-se como exemplo um texto da autoria de Eugène Lerminier (1803-1857) a respeito da Argélia, que estava sob o domínio francês desde 1830. Diante da rebeldia e resistência por parte dos argelinos, dizia o historiador, em 1836, que era preciso manter a Argélia, pois a posse do litoral africano era necessária "à segurança do império". Segundo sua interpretação, era fundamental para o comércio no Mediterrâneo que a França fosse "proprietária de um vasto território africano", garantindo igualmente uma "forte posição para contrabalançar Gibraltar [inglês], canhão sempre aberto, sempre armado". ${ }^{13}$

Nos artigos da Revue, algumas vezes, o passado se revestia de cores gloriosas, mas esmaecidas por tons melancólicos, lamentando-se o fato da França não ocupar mais o espaço de preeminência internacional que alcançara no século XVIII, até o reinado de Luís XV. Era essa a visão de Michel Chevalier (1806-1879), que escreveu artigos publicados na década de 1830, sobre sua visita oficial realizada aos Estados Unidos. Segundo

12 MAZADE, Charles de. Le socialisme dans l'Amérique Du Sud. Revue des Deux Mondes, Paris, v.XIV, p.641, 1852.

13 LERMINIER, Eugène. De la conservation d' Alger. Revue des Deux Mondes, Paris, v.VI, p.606, 1836. E continuava, mais adiante, na p.614: "A conservação da Argélia é tão necessária quanto justa, pois nossos interesses, dos mais particulares aos mais gerais, aí se encontram. É assim que as conveniências do sul da França combinam com as da França inteira e com as da Europa." Lerminier foi um historiador bastante conhecido e de tendência liberal. 
ele, naquele momento (1836), só restava aos franceses arrependimentos amargos, pois os ingleses os haviam derrotado tanto na América quanto nas Índias Orientais. Constatava que o idioma francês se perdia e os nomes das cidades e regiões exploradas pelos franceses se desfiguravam e se anglicizavam a ponto de ficarem irreconhecíveis. E, finalizava:

\begin{abstract}
Então nossa língua podia ter pretendido ser a língua universal. O nome francês tivera boas chances de se tornar o primeiro, não apenas como o dos gregos, no mundo das ideias, em virtude da literatura e das artes, mas também como o dos romanos, no mundo material e político, em função do número de homens que orgulhosos levavam o nome francês pelos imensos territórios que sua dominação cobria. (...) Nós mesmos nos esquecemos que houve um tempo quando poderíamos ter sido reis do Novo Mundo. ${ }^{14}$
\end{abstract}

Mas, como veremos adiante, a percepção da perda da importância internacional francesa não os impediria de construir propostas que a colocavam em primeiro plano frente à poderosa rival, a Grã-Bretanha, e ao jovem e "perigoso" país emergente, os Estados Unidos.

No período escolhido, a Revue publicou artigos sobre temas bastante variados referentes ao espaço latino-americano. Mas o México foi o alvo predileto dos editores - aproximadamente 30 artigos - indicando que os interesses franceses concentravam-se primordialmente naquele país. ${ }^{15} \mathrm{E}$ possível reconstituir as imagens construídas sobre o país e acompanhar as mudanças de perspectivas assumidas pelos colaboradores da revista nessas décadas.

A França reconheceu a independência do México em 1830 e, logo depois dessa data, iniciava-se um primeiro movimento dos comerciantes franceses em direção ao país. Uma segunda manifestação da presença francesa pode ser detectada na década de 1840, por ocasião da corrida do ouro à Califórnia, à época, província mexicana (será até 1848). Em 1849, os franceses eram a segunda nacionalidade estrangeira no México atrás apenas dos espanhóis. Isto explica, pelo menos em parte, o destacado número de textos encontrados na revista sobre esse país.

Salienta-se, ao primeiro olhar, uma série de artigos de Gabriel Ferry (1809-1852), que leva o título geral de Scenes de la vie méxicaine. Dentro da

14 CHEVALIER, Michel. Lettres sur l'Amérique. Revue des Deux Mondes, Paris, v.VIII, p.87, 1836. Importante observar que foi atribuída a Chevalier a invenção da denominação América Latina para justificar, por intermédio da identidade latina, as ambições da França sobre a região. A primazia da utilização do nome já foi questionada por Arturo Ardao. De todo modo, demonstra que as ligações francesas a essa parte do Novo Mundo eram bastante fortes. Sobre o debate, ver ARDAO, Arturo. Génesis de la idea y del nombre de América Latina. Caracas: Centro de Estudios Latinoamericanos 'Romulo Gallegos'/Consejo Nacional de la Cultura, 1980; QUIJADA, Mónica. Sobre el origen y difusión del nombre 'América Latina' (O una variación heterodoxa en torno al tema de la construcción social de la verdad). Revista de Indias, Madri, v.LVIII, n.214, p.602 e segs., 1998.

15 As edições completas da Revue estão disponíveis em formato digital no site da Bibliotéque Nationale de France, podendo ser acessadas por meio do seguinte endereço: http://www.gallica.bnf.fr. Para esta pesquisa, foram impressas e consultadas 2.000 páginas com todos os artigos sobre a América Latina. A partir daí, foram selecionados os textos sobre o México. 
perspectiva já anunciada, o colaborador da Revue legitimava suas narrativas pelo fato de se apresentar como "testemunha" dos fatos, pois vivera por quase 10 anos no México, na década de 1830, a mando da casa comercial de seu pai, o Barão Ferry de Bellemare. De volta à França, fora em seguida para a Espanha sempre em busca dos interesses comerciais da firma do pai. Pouco tempo depois, em vista de seu conhecimento sobre a América do Norte, foi designado pelo governo francês para funcionar como cônsul no porto de São Francisco, tratando dos imigrantes franceses que para ali tinham corrido em busca do ouro. Mas não chegou a seu destino, porque morreu tragicamente num incêndio que destruiu o navio inglês Amazonas, pouco tempo depois de este deixar a Inglaterra em direção à Califórnia. ${ }^{16}$

Muitos dos artigos de Ferry posteriormente se transformaram em livros, fazendo dele o primeiro autor francês de romances de aventuras sobre o Oeste, tendo o México como cenário. À época, foi mais prestigiado que Gustave Aimard, atualmente o mais conhecido autor desse gênero, cujos livros tinham como protagonistas aventureiros que cruzavam a região. Aimard escreveu, justificando sua "ação colonizadora", quatro volumes sobre as reais aventuras de Gaston de Raousset-Boulbon que pretendia, à frente de um pequeno exército, formar um estado independente em Sonora, no noroeste do México, como acontecera no Texas. ${ }^{17}$ Falhou nas duas tentativas (1852 e 1854) e acabou fuzilado pelo exército mexicano em Guaymas, em $1854 . .^{18}$

Em Sonora, havia uma forte tensão entre brancos e índios yaqui, que tentaram, sem sucesso, se separar do México depois da independência, o que provocou uma forte repressão por parte do Estado mexicano. ${ }^{19}$ Ferry percorreu a região e escreveu um artigo sobre a "guerra" em Sonora, estado mexicano que ele julgava com características particulares pelas vicissitudes das lutas com "as tribos indígenas à sua volta". ${ }^{20}$ Ferry narrava suas aventuras na primeira pessoa e se apresentava como parte integrante

16 George Sand escreveu o prefácio de um livro de Ferry publicado postumamente que se chama Les Révolutions du Méxique. Paris: E. Dentu, 1864. Nele, teceu muitos elogios à escrita de Ferry e também à sua "heróica morte" no incêndio do navio.

17 Ver os romances de Gustave Aimard: Le grand chef des Aucas (1858), La fièvre d'or (1860), La grande filibuste (1860) e Curumilla (1860); cf. VENAYRE, Sylvain. Le moment mexicain dans l'histoire française de l'aventure (18401860). Histoire et societé dans l'Amérique Latine, n.7, p.129, 1998.

18 O crítico literário Sylvain Venayre discute "o momento mexicano" na história francesa da Aventura, situando-o entre as décadas de 1840 e 1860. Ferry e Aimard construíram as imagens dos aventureiros de viagem: salteadores e contrabandistas, vaqueiros e gambusinos, que são os garimpeiros do ouro na Califórnia. Para ele, o discurso sobre a aventura está diretamente ligado à exploração e à colonização dos confins do planeta. Lembra que, em 1862, a França conquistava parcialmente a Cochinchina e pensava sua expansão pelo mundo. Não deve ser por acaso que Julio Verne publicava, em 1863, Cinco semanas em um balão, que conta a aventura de atravessar a África de leste a oeste. VENAYRE, Sylvain. Le moment mexicain dans l'histoire française de l'aventure (1840-1860), p.129.

19 A rebeldia yaqui provocou uma repressão muito forte durante o governo de Porfirio Díaz (1876-1911), culminando com uma marcha forçada dessa etnia que os obrigou a ir de Sonora até o Yucatán, onde os sobreviventes trabaIharam em condições de servidão.

20 FERRY, Gabriel. Une guerre en Sonora: souvenirs des cotes de l'Océan Pacifique. Revue des Deux Mondes, Paris, v.XIV, t.2, p.889-916, 1846 
das tramas, num relato com muita ação e batalhas e cujo núcleo versava sobre as relações entre brancos e índios yaqui. Para além da esperada interpretação sobre os indígenas - aliados ou inimigos - sempre entendidos como temíveis e tratados com desconfiança, para meus objetivos, o interesse deste artigo está nas manifestações do autor a respeito do lugar político da França.

Contava, por exemplo, que estava entrando em uma taberna no porto de Guaymas, quando um homem alto, olhos negros, "traços característicos" de mexicano, saudou-o com as seguintes palavras: "Seja bem vindo, senhor Francês, porque sua nação não tem servos em seu seio." Em seguida, do fundo do salão, ouviu-se outra voz, a de um velho sargento mexicano, que continuou: "A França é uma grande nação e o imperador Napoleão um grande homem!"21 Nunca saberemos ao certo se este episódio aconteceu e se essas frases foram assim pronunciadas. O importante é assinalar as intenções do autor. Ao colocar, no extremo oeste mexicano, dois nativos declarando seu respeito e sua admiração pela França e por Napoleão, Ferry estava produzindo em seus leitores o efeito positivo de que testemunhou o quanto o "povo" mexicano era receptivo aos valores franceses, guardando ainda na memória as façanhas do imperador corso.

Nesse mesmo artigo, Ferry demarcava sua visão sobre as relações entre o México e os Estados Unidos. Para ele, nenhum país como o México era "mais fecundo em revoluções", que aconteciam por "causas fúteis" e chegavam a "resultados inesperados". ${ }^{22}$ Com olhar distanciado, como se estivesse assistindo a um espetáculo, afirmava que "esses mil incidentes", "essa turbulenta aprendizagem da vida política" era muito conveniente para os viajantes, pois brevemente esses costumes excêntricos iriam desaparecer. Mais alguns anos, e o país mudaria:

Como o Texas, Sonora está destinado a ser tomado pelos Estados Unidos e não está longe o tempo em que a União contará com Guaymas como um porto no Oceano Pacífico. ${ }^{23}$

A presença dos Estados Unidos no México foi tema importante para muitos outros articulistas da Revue que percebiam a força norte-americana em oposição à debilidade mexicana, o que os levava a incentivar a França a assumir a liderança que "a História Ihe reservara" e a tomar iniciativas concretas. Como se sabe, assim acontecerá na década de 1860, no governo de Napoleão III.

21 FERRY, Gabriel. Une guerre en Sonora: souvenirs des cotes de l'Océan Pacifique, p.899.

22 FERRY, Gabriel. Une guerre en Sonora: souvenirs des cotes de l'Océan Pacifique, p.889.

23 FERRY, Gabriel. Une guerre en Sonora: souvenirs des cotes de l'Océan Pacifique, p.889. 
Nessas narrativas de aventura, Ferry mostrava o México como um lugar exótico, o que não se constitui em novidade, já que essa era a perspectiva hegemônica dos europeus sobre a América Latina em geral. Mas em outro artigo da série Scènes, que se chama Frei Serapio, publicado em 1847, Ferry realçava algumas diferenças entre a Europa e o México. ${ }^{24}$ Nesse país, a história havia parado no tempo, lá se encontrando costumes e comportamentos que não mais existiam na "Europa civilizada". Para ele, o México era ainda a Espanha numa versão primitiva. Voltando-se para a questão religiosa, declarava que a Europa havia rompido completamente com os princípios e as tradições da Idade Média, mas o mesmo não acontecia no México. Ali os frades continuavam a ter uma grande influência, estabelecendo uma estreita ligação entre o claustro e o mundo. Para Ferry, um dos grandes atrativos do México era perceber a existência de tipos e costumes próprios do tempo de Felipe II em pleno século XIX: homens que portavam espadas, mulheres vestidas como as contemporâneas de Pizarro e Cortez, índios de pernas nuas calçados com sandálias antigas. Nesse quadro, os hábitos dos frades apareciam não como anomalia, mas como uma "poética lembrança" do passado. As cerimônias religiosas eram numerosas e as procissões serpenteavam pelas ruas. Segundo o autor, apenas as classes altas se livraram das influências monásticas, mas as classes médias continuavam a ouvir o clero com a "mesma veneração supersticiosa de um século atrás". ${ }^{25}$ Para provar sua tese, conta a história de dois frades franciscanos, Frei Serapio, que "casou a piedade à libertinagem", e frei Epigmênio, que erigiu a piedade em fanatismo religioso. ${ }^{26}$ Os monges, assim, não eram figuras louváveis. Sua pergunta ao fim do texto assim se resumia: o contraste entre os dois frades "resumiria a vida monástica mexicana?"27

Vivendo em uma temporalidade que não mais existia no mundo civilizado, o México era apresentado como uma região que precisava ser "atualizada" e lapidada por europeus, deixando o mundo das "crendices" para entrar numa era secularizada. Nesses aparentemente despretensiosos artigos de Ferry, visualizavam-se aventuras rocambolescas que se desenrolavam numa natureza poderosa e misteriosa com tipos humanos que ainda viviam em uma sociedade pré-moderna, sem leis, com superstições e com códigos de honra dos tempos medievais. Como autor, Ferry observava de fora esse universo "bárbaro" repleto de emoções, de sentimentos que explodiam, com seres humanos ainda incapazes de se auto-controlar de

\footnotetext{
24 FERRY, Gabriel. Scènes de la vie mexicaine: Fray Serapio. Revue des Deux Mondes, Paris, v. XIX, t.3, p.820-848, 1847.

25 FERRY, Gabriel. Scènes de la vie mexicaine: Fray Serapio, p.822.

26 Epigmênio acreditava ser um santo, lutando constantemente contra o demônio e as tentações; no entanto, em circunstâncias misteriosas, se encontrou com uma moça, "caiu em tentação", confessou publicamente seu pecado diante da Inquisição (que ainda existia no momento da narrativa) e foi absolvido; a moça, entretanto, vítima inocente do frei, foi presa, julgada e condenada à morte por "ter parte com o demônio".

27 FERRY, Gabriel. Scènes de la vie mexicaine: Fray Serapio, p.848.
} 
forma racional. Escreveu sobre as paisagens distantes do México, inventando grande parte da mitologia sobre a região, podendo ser integrado à tradição romântica, que trabalhava com a ideia de que, nas regiões abertas da América, paixões desenfreadas acabavam por se revelar.

Nos artigos mencionados, Ferry discorria sobre episódios aos quais ele conferia dramaticidade e comicidade. Seu texto ganha tonalidades de sóbria análise quando o tema é a guerra entre os Estados Unidos e o México. ${ }^{28}$ O autor não justificava a invasão dos Estados Unidos, indicando que os problemas levantados por ocasião da definição das fronteiras com o Texas "não autorizavam de nenhuma maneira os Estados Unidos a invadir, além do território contestado, as mais ricas províncias do México". ${ }^{29}$ Lamentava que, por ocasião da anexação do Texas à União, as diplomacias inglesa e francesa tivessem ajudado a engrandecer o território norte-americano e a acrescentar um estado escravista ao país. Criticava o governo da França que manifestara "indiferença e preocupação medíocre" com o progresso dos Estados Unidos e seu avanço territorial no México. ${ }^{30}$

Ao descrever muitas batalhas, mostrava, com certo abatimento, as notáveis diferenças entre os exércitos norte-americanos e mexicanos. Ao lado dos "robustos e taciturnos" filhos do Kentucky, armados com rifles de cano longo, dos "gigantescos caçadores" da Virgínia, encontravam-se os soldados mexicanos: índios, brancos ou mestiços, todos pequenos, magros, mal vestidos, sem sapatos e sem alimentação adequada, mas que lutavam intrepidamente com armas brancas, ainda que não tivessem familiaridade com os fuzis. ${ }^{31}$ No momento em que escrevia, a guerra ainda não havia terminado, mas ele não tinha dúvidas de quem venceria. Aliás, o exército dos Estados Unidos, naquela data, estava mesmo prestes a entrar na capital do México. Culpava "a nação mexicana" por não demonstrar, em presença do perigo, as virtudes com as quais se reconheciam os grandes povos, mas, por outro lado, afirmava que o México merecia o direito à "nossa" simpatia. ${ }^{32}$ Preocupado com o tratado de paz, indagava até onde iriam as fronteiras dos Estados Unidos, manifestando sua consternação com o poder dos Estados Unidos que podiam "ameaçar os interesses da Europa". Esta não podia acompanhar sem inquietação os "progressos incessantes" da América do Norte. Levando esse raciocínio até as últimas consequências, cogitava a possibilidade do desaparecimento "das nacionalidades vizinhas da União" e os graves prejuízos para os interesses franceses.

Sua segunda conclusão revelava a visão que seria a dos dirigentes da França nas décadas seguintes. Ao se perguntar se ainda havia na nação

28 FERRY, Gabriel. La guerre des États-Unis et du Méxique. Revue des Deux Mondes, Paris, v.XIX, t.3, p.385-431, 1847.

29 FERRY, Gabriel. La guerre des États-Unis et du Méxique, p.386.

30 FERRY, Gabriel. La guerre des États-Unis et du Méxique, p.386.

31 FERRY, Gabriel. La guerre des États-Unis et du Méxique, p.390.

32 FERRY, Gabriel. La guerre des États-Unis et du Méxique, p.426. 
mexicana "elementos de ordem e de estabilidade" que pudessem fazer frente aos projetos norte-americanos, respondia que a única força política nova e capaz de desempenhar esse papel era o partido monárquico que, no meio da desorganização crescente, aparecia como o único a ter sinais de vitalidade. ${ }^{33}$ Desse modo, a França deveria promover uma aproximação com o partido monarquista e fazer o México superar sua "grande fraqueza", a de ter evitado os europeus ao invés de acolhê-los com reconhecimento, olhando para o progresso do Velho Mundo. ${ }^{34}$

Finalmente, Ferry refletia sobre as diferenças de "raça" e religião. Referia-se a "uma invasão protestante", determinada em parte pelos interesses das nações industriais e comerciantes e, por outro, pela indiferença dos ricos proprietários franceses estabelecidos no México. ${ }^{35}$ As peripécias da guerra haviam mostrado "como a raça espanhola deixada a si mesma" não tinha condições "de opor resistência séria à raça anglo-saxã." Para estabelecer um equilíbrio entre as duas raças era preciso que a Europa (vale dizer, a França) ajudasse as jovens nações da América:

Quanto mais a audaciosa atividade dos Estados Unidos merece nossa admiração, mais ela nos impõe nossa solicitude e prevenção. Mais que nunca em presença da guerra do México não é permitido à Europa esquecer que ela tem no Novo Mundo, entre um Estado que cresce a cada dia e infelizes sociedades jogadas em uma anarquia sempre avolumada, interesses a proteger, princípios a defender, uma influência preciosa a manter. ${ }^{36}$

Nessa mesma linha de pensamento, Félix Clavé (1811-1853), católico e monarquista, que também havia vivido por algum tempo no México, publicou, em 1845, um artigo em que apresentava a situação do México no período da incorporação do Texas aos Estados Unidos e da demarcação dos limites entre os dois países. ${ }^{37}$ Entendia que, na América do Norte, os Estados Unidos disputavam diversos territórios com a Inglaterra, como o Oregon e o norte da Califórnia. Na América Central, as contendas se concentravam na Nicarágua, onde se pretendia abrir um canal interoceânico. Na perspectiva do autor, a França tomara posições políticas tardias e não estabelecera "sua influência sobre uma base mais larga e durável" ${ }^{38}$ De maneira clara, advertia:

33 FERRY, Gabriel. La guerre des États-Unis et du Méxique, p.427-429.

34 E continuava: "O estudo de nossas instituições, de nossas ideias, eis o que pode levantar esta nação abatida". FERRY, Gabriel. La guerre des États-Unis et du Méxique, p.430.

35 FERRY, Gabriel. La guerre des États-Unis et du Méxique, p.430.

36 FERRY, Gabriel. La guerre des États-Unis et du Méxique, p.431.

37 CLAVÉ, Félix. La question du Méxique: relations du Méxique avec les État-Unis, l'Anglaterre et la France. Revue des Deux Mondes, Paris, v.X, t.4, p.1029-1059, 1845.

38 E completava: "Vamos permitir que nossos futuros destinos sejam debatidos sem nossa intervenção?". CLAVÉ, Félix. La question du Méxique, p.1029-1030. 
Os EUA preparavam há vinte anos a conquista do norte do México; o pretexto que Ihes faltava para conseguir, encontraram com a anexação do Texas. ${ }^{39}$

Para Clavé, a França adotara atitudes completamente "passivas" com relação ao México. Essa "culpável indiferença" precisava ser superada com o desenvolvimento do comércio francês e com o envio de um número considerável de população europeia ao país. ${ }^{40} \mathrm{~A}$ França precisava desempenhar um papel "ativo", interferindo e estimulando a economia mexicana a ponto de fazer surgir um país rico. Desejava promover uma mudança no jogo de xadrez habitual. Constatava que a França fizera a escolha de dirigir sua produção industrial e seu comércio (de luxo) somente aos países onde reinava "uma civilização avançada", enquanto que a Inglaterra e os EUA forneciam bens (baratos) a "nações atrasadas". O México seria o epicentro da modificação de rumos, pois se transformaria em nação rica e poderosa graças à França, que conseguiria, assim, parar na América "o avanço" da Inglaterra e dos EUA. Terminava o texto de forma dramática, dizendo que se a França continuasse a manter uma posição "passiva", seria melhor romper as relações com os estados mexicanos e retomá-las "quando eles tivessem sido incorporados à União ou vendidos à Inglaterra". ${ }^{41}$

O tema da necessidade de uma marcante presença da França no contexto americano mereceu outros artigos como o de Xavier Raymond (1812-1866). ${ }^{42}$ Este autor, que conhecia bem as questões das marinhas francesa e britânica, apresentava as negociações entre a Inglaterra e os Estados Unidos para a abertura de um canal pela Nicarágua, ligando o oceano Atlântico ao Pacífico. Essas conversações, das quais a França não participou, culminaram com a assinatura do tratado Clayton-Bulwer entre Grã-Bretanha e Estados Unidos. ${ }^{43} \mathrm{~A}$ análise do articulista para entender a ausência francesa passava por uma reflexão sobre "raça", religião e poder. Para ele, o mundo estava dividido, de uma parte, entre anglo-saxões e latinos e, de outra, entre protestantes e católicos. Todos os "povos de raça latina ou de religião católica" estavam em decadência se comparados ao extraordinário desenvolvimento da "raça anglo-saxônica" e "protestante". Tomava, como exemplos da raça latina, os "atrasados" Portugal e Espanha, ao lado da "triste Itália"; e dos países católicos, "a infeliz Polônia" e "a deplorável Irlanda". A única exceção se constituía na França, que "entre suas irmãs de sangue", continuava como "potência de primeira ordem". A superioridade anglo-saxônica era notável. No Novo Mundo, a Inglaterra

39 CLAVÉ, Félix. La question du Méxique, p.1036-1037

40 CLAVÉ, Félix. La question du Méxique, p.1044.

41 CLAVÉ, Félix. La question du Méxique, p.1059.

42 RAYMOND, Xavier. De la rivalité de l'Anglaterre et dês États-Unis: les anglais et les américains au Méxique et dans l'Amérique Central. Revue des Deux Mondes, Paris, v.II, p.298-333, 1853.

43 Pelo tratado Clayton-Bulwer, em 1850, a Grã-Bretanha e os Estados Unidos se comprometiam a não iniciar os trabalhos de abertura de um canal interoceânico sem que o outro fosse informado com antecedência. 
tinha um único rival à sua altura: os Estados Unidos com seu progresso e "sua crescente intervenção" no resto do continente, que faria esse país levar sua bandeira e ocupar o istmo do Panamá, permitindo-lhe aspirar à preponderância sobre os dois oceanos. ${ }^{44}$

Nos anos até aqui analisados, a Revue acolheu articulistas que, pretendendo falar em nome da França, apresentaram o México como país exótico, atrasado, anárquico, vivendo nos tempos de Felipe II, e que necessitava de amparo forte e decisivo por parte da "primeira nação das Luzes". Igualmente aparecia o sentimento de admiração que os mexicanos nutriam pela França.

A década de 1860 se constitui em período singular para a análise da Revue em relação ao México, pois há alterações na visão até então dominante. Como se sabe, para assegurar e ampliar os seus interesses, a França, sob Napoleão III, ordenara a invasão do México, em 1862, em consórcio com Espanha e Inglaterra, a fim de cobrar dívidas não saldadas pelo governo de Benito Juárez. Poucos meses depois, a Espanha e a Inglaterra se retiraram, deixando os franceses sozinhos. Entretanto, a França levou avante seu projeto imperial, articulando - com grupos monárquicos do Partido Conservador mexicano - a coroação, em 1864, do arquiduque Maximiliano de Habsburgo, irmão do imperador austro-húngaro Francisco José I, como monarca do Império mexicano. As tropas francesas que sustentaram com as armas esse governo foram derrotadas pelos liberais mexicanos liderados pelo presidente Benito Juárez. O julgamento e fuzilamento de Maximiliano, em 1867, ao lado de dois generais mexicanos do Partido Conservador, marcam a derrocada do projeto francês..$^{45}$

A intervenção armada de 1862 foi entendida, num primeiro momento, pela Revue, como uma necessidade europeia. Porém, no segundo semestre de 1862, quando o exército francês já não contava com o apoio dos demais países europeus, Charles de Mazade, um dos responsáveis, nesse período, pela linha política da Revue, escreveu sobre esses acontecimentos. O México, que o autor nunca visitara, era apresentado, repetindo as palavras de Gabriel Férry, como o local onde se assistia ao espetáculo de "indescritível anarquia", atravessado por uma guerra civil que durava sete anos e se constituía em "condição fatal e permanente do país" ${ }^{46}$ Menosprezava Benito Juárez, o presidente representante da "raça indígena" que se caracterizava por "paixões, ardis, fanatismo e ambição". Dessa "sociedade incoerente", com sete milhões de habitantes e apenas um milhão de europeus, nada se podia esperar. ${ }^{47} \mathrm{~A}$ combinação entre a "anarquia mexicana" e a "ambição

44 RAYMOND, Xavier. De la rivalité de l'Anglaterre et dês États-Unis, p.333.

45 Quando os franceses chegaram ao México, Benito Juárez era o presidente da República; jamais renunciou ao cargo, permanecendo como líder da resistência republicana e liberal até o final da guerra civil.

46 MAZADE, Charles de. La guerre du Méxique et les puissances européennes. Revue des Deux Mondes, Paris, v.XL, p.734, 1862

47 MAZADE, Charles de. La guerre du Méxique et les puissances européennes, p.735. 
norte-americana" deixava entrever a concreta possibilidade da anexação do México ao país do norte, fato que poria em risco os "interesses da Europa". Desse modo, não havia restado outra alternativa senão a invasão. ${ }^{48}$ Tentava entender as razões do "abandono" da França pela Espanha e pela Inglaterra, referindo-se, pela primeira vez, à palavra erro. Segundo o autor, a França deveria ter entrado em tal empresa conhecendo exatamente os objetivos a serem alcançados, as dificuldades reais a serem enfrentadas e um plano de ação comum das três potências. ${ }^{49}$

A admissão por parte de Mazade de "dificuldades reais a serem enfrentadas" estava provavelmente associada às surpresas vivenciadas pelos franceses depois do desembarque em terras mexicanas. As tropas francesas que caminhavam do porto de Veracruz em direção à capital, aproximaramse de Puebla. O comandante francês, conde de Lorencez, confiante na superioridade numérica de suas forças bem equipadas e menosprezando os "desorganizados e indisciplinados" soldados inimigos, em 5 de maio de 1862, atacou Puebla na certeza de que as tropas mexicanas se renderiam e fugiriam. No entanto, elas resistiram às cargas francesas por três vezes e contra-atacaram. Os franceses foram derrotados e Puebla não se rendeu, mas isto não impediu que, posteriormente, a Cidade do México fosse tomada. Entretanto, a bravura dos mexicanos em Puebla demonstrou que o país não estava à espera de "salvadores" estrangeiros.

Assim se explica a cautela das opiniões de Mazade no artigo anteriormente mencionado; um ano depois, no final de 1863, o autor estava bastante preocupado com a situação da França no México e com os planos de sustentação de uma monarquia no Novo Mundo. Afirmava que Michel Chevalier (1806-1879) - também colaborador da Revue e grande incentivador do expansionismo de Napoleão III - tinha um vasto programa para a monarquia mexicana que abrangia a criação de um exército, a reorganização das finanças, a reforma do ensino e as mudanças do clero. Mas Mazade apontava para uma questão crucial, a da conciliação entre "solidariedade comprometida" e ocupação militar indefinida, indicando claramente um certo desconforto de parte das elites francesas com a política externa de Napoleão III. ${ }^{50}$ Também demonstrava apreensão com as "distorções da imagem civilizadora" da França na América Espanhola, onde a "expedição do México", segundo ele, era mal compreendida e mal conhecida. A hosti-

48 MAZADE, Charles de. La guerre du Méxique et les puissances européennes, p.738.

49 MAZADE, Charles de. La guerre du Méxique et les puissances européennes, p.761.

50 E deixava explicitado: "Poderia aceitar esta responsabilidade de fazer viver um império do outro lado do Atlântico, de defender o México contra sua própria anarquia, e de garantir os empréstimos franceses? Se a França impuser suas decisões será uma dominação abusiva, uma conquista; se ela prestar seu socorro a um partido ou à monarquia, sem ter o direito de dirigir um programa político, corre o risco de ajudar - sem querer - o triunfo de ideias que não são as suas, que são aquelas da política que ela combate na Europa. Assim, a França está se aventurando no desconhecido"; MAZADE, Charles de. L'expédition du Méxique et la politique française. Revue des Deux Mondes, Paris, v.XLVIII, p.675-706, 1863. 
lidade dos Estados hispano-americanos mostrava-se "pueril e injusta", pois a França trabalhava pela "regeneração" do México e não pretendia avançar por outros territórios americanos. Entretanto, concluía que o melhor seria deixar o México livre para se reorganizar e se reconstituir em condições de independência, mas estas seriam enganosas se o país necessitasse se manter "sob a proteção permanente de uma bandeira estrangeira, mesmo que fosse a bandeira desinteressada e gloriosa da França". ${ }^{51}$

Os dois últimos artigos a serem analisados, são de autoria do conde Émile de Keratry (1832-1904), que participou da expedição do México. ${ }^{52}$ No início de 1866, como testemunha dos fatos, descreveu com detalhes, citando muitos nomes, cidades e datas, as lutas de guerrilhas no estado de Tamaulipas, que se desenrolavam desde 1864. A conclusão do texto sinalizava a possibilidade da derrota francesa, pois já indagava se os milhões empregados na guerra não poderiam ter sido melhor aplicados em outras colônias francesas. Terminava o artigo, declarando que as campanhas no estado de Tamaulipas revelavam dois fatos significativos: "o espírito hostil da população mexicana e a frieza de nossos próprios compatriotas que se perguntam com apreensão quais serão os resultados de tantas lutas e fadigas". ${ }^{33}$

Em setembro/outubro do mesmo ano de 1866, data do já visível declínio da monarquia de Maximiliano de Habsburgo, o conde de Keratry publicava outro artigo no qual demonstrava grande inquietação com os destinos da França no México. Afirmava que, no palácio imperial, a palavra abdicação era murmurada constantemente. ${ }^{54} \mathrm{Na}$ perspectiva do autor, o imperador não foi compreendido em seu desejo de "dirigir a regeneração do povo mexicano" e de lhe trazer "paz e riqueza". Mas ele errou ao ser "muito liberal", pois o povo (isto é, os índios) estava disposto a se jogar nos braços do imperador se este tivesse mostrado energia e firmeza. Por outro lado, uma série de fatores - o clero corrupto, os oportunistas, a penúria do tesouro público, as fraudes, as dilapidações, o apoio discreto do governo dos Estados Unidos a Juárez - contribuíram para seu enfraquecimento. De forma coerente, não fazia qualquer menção à forte oposição mexicana - republicana e liberal - ao monarca estrangeiro, que foi central para a derrocada do Império. Desse modo, terminava o artigo propondo um programa para um futuro governo monárquico no México.

51 MAZADE, Charles de. L'expédition du Méxique et la politique française, p.704 e p.706.

52 Mais tarde, o autor foi defensor da guerra franco-prussiana.

53 KÉRATRY, Émile de. La contre-guérrilla française au Méxique: souvenirs des terres chaudes. Revue des Deux Mondes, Paris, v.LXI, p.775, 1866.

54 KÉRATRY, Émile de. Le Méxique et les chances de salut du nouvel empire. Revue des Deux Mondes, Paris, v.LXV, p.443, 1866. Maximiliano adotara o neto do ex-imperador, Agustín de Iturbide, como seu filho e sucessor. 
Depois da derrota da França e do fuzilamento de Maximiliano em 1867, não foram encontrados na Revue, até 1870, artigos sobre a situação do México. Apenas um breve comentário, na sessão Chronique de la Quinzaine, no exemplar de novembro/dezembro de 1867. Num texto de análise da situação política internacional, o autor, Eugène Forcade (1820-1869), relembrava "o hábito de uma longa passividade" por parte da França e afirmava que sua política exterior deveria de agora em diante se pautar por aspirações internas e não por desejos externos; a intervenção francesa no México tinha sido um "desastre doloroso e humilhante". ${ }^{55}$

Ao finalizar a análise dos artigos da Revue des Deux Mondes sobre o México, no período indicado, alguns pontos devem ser salientados. A revista expressava a opinião de grupos de intelectuais próximos ao poder político vigente, entendidos como representantes dos interesses nacionais franceses. Com relação à América Latina, o México se distinguia como centro principal de suas atenções. Nas décadas de 1840 e 1850, a revista elaborou imagens da França como a nação latina civilizada, culta e heróica, que se preocupava com sua "irmã de sangue" mexicana, pobre, fraca, desprotegida, anárquica, em busca de uma bússola que a guiasse. Os artigos lembravam o glorioso passado da França e insistiam na necessidade do país se interpor ao avanço, na região, de sua grande rival, a Grã-Bretanha, e da nova "ameaça", os Estados Unidos. Os articulistas estimularam seus leitores a pensarem a França como grande potência colocada em lugar de preeminência internacional legitimado por sua história, cultura e civilização.

O projeto de Napoleão III de articular e apoiar a monarquia de Maximiliano de Habsburgo foi entendido pela Revue, no início, como uma decisão que poderia trazer benefícios à França. Porém, o desenrolar dos acontecimentos e a forte (e inesperada) resistência mexicana, liderada por Benito Juárez, mudaram as perspectivas dos articulistas que passaram a se manifestar de forma cautelosa e apreensiva sobre o destino da "aventura" francesa no México. O silêncio a respeito do trágico fim do monarca austríaco e da derrota das forças francesas sugere que a Revue havia compreendido a dimensão do fracasso do projeto imperial francês no México.

À guisa de conclusão, vale sublinhar que as pretensões de hegemonia da França na América Latina sofreram um segundo golpe com o malogro francês na tentativa de construção do Canal do Panamá. ${ }^{56}$ Esse insucesso

55 FORCADE, Eugène. Chronique de la quinzaine. Revue des Deux Mondes, Paris, v.LXXII, 1867, p.761.

56 Em 1878, o famoso engenheiro francês, Ferdinand Lesseps, responsável pela abertura do Canal de Suez em 1869, propôs realizar a sonhada tarefa de abrir um canal interoceânico no istmo de Panamá. Levantou o capital necessário e obteve o consentimento do governo da Colômbia. Entretanto, seu empreendimento foi um terrível fiasco. Ele enfrentou problemas técnicos insuperáveis - tipo de terreno, relevo e clima - que levaram sua empresa à falência. Por outro lado, a malária e a febre amarela mataram aproximadamente 20.000 trabalhadores. Como se sabe, os Estados Unidos compraram a massa falida francesa e construíram, superando os problemas tecnológicos e de saúde pública, o Canal do Panamá, inaugurado em 1914. 
selou o lugar secundário da França na América Latina do século XX, fazendo dela apenas um ator coadjuvante frente ao poder geopolítico e econômico da Inglaterra e dos Estados Unidos na região. ${ }^{57}$

57 Não se pode dizer o mesmo sobre o domínio francês em outras partes do globo, como a África e a Ásia, onde a França se manteve como potência colonialista até depois da Segunda Guerra Mundial. Também se assinale que, na América Latina, a França mantém sob seu domínio, até o presente, a Guiana Francesa e algumas ilhas do Caribe, como Martinica e Guadalupe. 